\title{
The use of ITS region as a tool for wood identification in Brazil: A case study of a tree from the genus Hovenia sp.
}

\author{
Felipe Zatt Schardosin, Pedro Henrique Gonzalez de Cademartori, Simone Ribeiro Morrone, \\ Graciela Inés Bolzon de Muñiz, Silvana Nisgoski*
}

Departamento de Engenharia e Tecnologia Florestal, Universidade Federal do Paraná, Curitiba, PR, Brasil.

\begin{abstract}
The knowledge of botanical identity of wood allows its adequate application as raw material in the industry and has importance related to deterring the illegal trade in protected species. This paper reports the species identification of seized logs, based on anatomical characteristics and ITS (Internal Transcribed Spacer) region. Three wood samples came from an apprehension in deforestation in Paraná State, Brazil, by the Federal Police, resulting from actions to combat illegal logging. First anatomical identification was done based on the macroscopic and microscopic characteristics of material. After, DNA extraction was done with the DNeasy Mericon Food Kit ${ }^{\circ}$ with some adaptation. Wood presented growth rings distinct, semiring porous, vessels solitary predominant, in radial multiples of 2-3, occasionally clustered, without deposits in vessels, axial parenchyma unilateral and vasicentric, tending to lozenge-aliform, confluent and in marginal bands, heterogeneous rays, uniseriate and multiseriate, not storied, fibers thin to thick-walled, non-septate and was identified as from genus Hovenia. ITS1 region resulted in the same genus and allowed the identification of the seized sample, which is an exotic and invader species that can be explored.
\end{abstract}

Keywords: DNA-barcoding; transcribed internal spacers; species discrimination; wood characteristics; illegal logging.

\section{Introduction}

Knowledge of the botanical identity of wood allows its adequate application as raw material in wood industry, and has importance related to deterring illegal commerce of protected species. The most common method applied for wood identification is based on the sample's organoleptic properties and description of anatomic characteristics at macro and microscopic levels and so the characteristics observed can be used by comparison with taxonomic identification keys, descriptions in the literature and samples in reference collections (WHEELER; BASS, 1998). This process is slow and requires professionals with knowledge of wood anatomy (KOCH et al., 2011; SARMIENTO et al., 2011). The resulting identification is usually no more accurate than the genus level, and in some cases only the botanical family can be identified (GASSON, 2011; HANSENS et al., 2011).

One alternative to increase the accuracy and success rate of species identification is DNA based techniques, where the sequencing of some genome regions allows comparison with previously generated sequences from genetic data banks (FORD et al., 2009; LOWE; CROSS, 2011). The diversity of DNA sequences in organisms can be exploited in the same way as barcodes on products. Different loci are evaluated and various tools, computer programs and databases are used with adequate precision, although in some cases still resulting in confusion in the case of closely related taxa (BARGAVA; SHARMA, 2012; LI et al., 2015).

An advantage of DNA barcoding is that once a solid reference database has been established, the method does not require expert taxonomic knowledge in order to identify 
specific samples and identification can be done with small tissue samples and does not require reproductive material. On the other hand, a disadvantage is that it has not been identified a single universal DNA region that can be used across all taxonomic groups (HARTVIG et al., 2015).

The choice of short target regions with large numbers of replicates in the genome increases the success rate of DNA sequencing (RACHMAYANTI et al., 2009; FINKELDEY et al., 2010). Within the genome of a specimen, although there are many coding genes, much of the DNA is composed of non-coding regions, which are repeated successively. Mutations occurring in these regions are easily transmitted, so they have high variability and good potential for phylogenetic studies and species differentiation (WICKE et al., 2011).

Different markers are applied in DNA-barcoding, as cpDNA and mDNA markers, like traditional regions $r b c L$, $m a t K, t r n H-p s b A$ from plastidial DNA and ITS region from nuclear DNA. The China Plant BOL Group (2011) verified the application of ITS (Internal Transcribed Spacer) region as a complementary DNA-barcoding for 1575 species, 145 genera and 75 families. For $88 \%$ of angiosperm samples and $56 \%$ of gymnosperm samples, the amplification was effective, and the sequencing success rates were $89.8 \%$ and $67 \%$ for angiosperms and gymnosperms, respectively.

The ITS region was applied in medicinal plant discrimination (GAO et al., 2010), and as a marker for the identification and distinction of wood with similar macroscopic structure (HANSEN et al., 2011). Bolson et al. (2015) reported success in applying the ITS marker associated with plastidial DNA for the identification of arboreal species in Southern Brazilian Atlantic rainforests, being the first and only work for the species of that region. However, the extractions were from leaves, which generated higher quality DNA isolates (FINKELDEY et al., 2010).
Recent studies with wood samples and ITS region isolated or with other markers showed promising results, as in Dalbergia (HARTVIG et al., 2015; YU et al., 2016, 2017) and Pterocapus (JIAO et al., 2018) species discrimination. In wood, DNA analysis is more difficult because of the death of cells and heartwood formation. In these steps, DNA is quickly degraded and the molecules can be attacked by bacteria, fungi and insects resulting in contaminations (MAGEL, 2001). Zhang et al. (2015) observed and quantified nuclei and plastids adhered to the walls of parenchyma cells in heartwood and sapwood. They also verified these structures continue to be degraded after the tree is cut and while the logs are stored or dried. Even after the drying process, DNA isolation is still possible, but the quantity isolated and the success rate of amplification and sequencing fall significantly (TNAH et al., 2012).

The yield in DNA isolation from wood can show differences between species, within the same species, and even between different positions in the same trunk (FINKELDEY et al., 2010). The literature reports, with diverse yield results and success rates from sequencing, the use of DNA in studies of ancient wood samples (LIEPELT et al., 2006), to verify the geographic origin of mahogany (Swietenia macrophylla King) (DEGEN et al., 2013), of processed wood or heartwood (ASIF; CANNON, 2005; BORGES et al., 2017), to identify positions between cambium and pith (RACHMAYANTI et al., 2009), with kiln-dried samples and samples from a xylotheque stored for 39 years (JIAO et al., 2014), and to provide evidence of illegal logging (TEREBA et al., 2017), among others.

In this context, this work reports the identification of wood samples obtained in an illegal logging, based on anatomical characteristics and ITS region to verify if it was an endangered species. 


\section{Material and Methods}

Three wood samples, without identification of position in tree or other detail, came from an apprehension in deforestation in Paraná State, Brazil, done by the Federal Police as result of actions to combat illegal logging. The Police suspected that species was in the list of endangered one.

\section{Anatomic identification}

The samples were initially observed under a Zeiss Discovery V12 stereomicroscope to describe the macroscopic characteristics, and high-resolution images were obtained from both radial and tangential sections. Samples were boiled in water and transversal, radial and tangential sections were obtained with thickness of $25 \mu \mathrm{m}$. The sections were dyed with chrysoidine, acridine red and Astra Blue (DUJARDIN, 1964). Microscopic description was done in accordance with International Association of Wood Anatomists (IAWA, 1989) and images were obtained with a Leica DM 4000 microscope. Also, Scanning Electron Microscopy (SEM) images were obtained with a Hitachi TM-1000 tabletop microscope.

From the anatomical description of samples, the identification was done based on: 1) the online key for wood identification of InsideWood (2004); and 2) the wood identification key developed by Record; Hess (1949). After a previous identification of genus, some micrographs from histological slices were obtained from species Citharexylum myrianthum and Hovenia dulcis for comparison. Material is from scientific collection of Laboratory of Wood Anatomy, from Federal University of Paraná, Brazil.

\section{Biomolecular identification - DNA}

The DNA was extracted with the DNeasy mericon Food Kit $^{\circledR}$ (Qiagen, Hilden, Germany) with some adaptation.
Samples, were prepared in the following steps: 1) the external surface of wood was cleaned with a surgical scalpel; 2) the material was reduced to dust with a metallic grater on aluminum foil; 3) $700 \mathrm{mg}$ was macerated with a mortar and pestle with the help of liquid nitrogen, followed by addition of $5 \mathrm{ml}$ of food lysis buffer solution and new maceration; 4) another $5 \mathrm{ml}$ of buffer solution was added and the entire volume was transferred to a Falcon tube containing $25 \mu \mathrm{l}$ of proteinase $\mathrm{K}$; 5) the Falcon tube was incubated at $60^{\circ} \mathrm{C}$ for 60 min in a water bath, with agitation by vortex each 15 minutes; 6) after incubation, the tube was centrifuged at $2500 \mathrm{~g}$ for 5 minutes; 7) the supernatant was isolated and washed in chloroform (proportion 10:7). All these steps followed the manufacturer's recommendations.

The level of fragmentation in isolated DNA was evaluated in $2 \%$ agarose gel for 60 minutes at $110 \mathrm{~V}$. Then $5 \mu \mathrm{l}$ of isolated plus $2 \mu$ l of buffer sample $(0.25 \%$ bromine phenol and $0.75 \%$ glycerin) were added. The gel was dyed with ethidium bromine at $0.000002 \%$ for $10 \mathrm{~min}$, washed in distilled water and photographed with a transilluminator. DNA concentration and quality were determined in a spectrophotometer in a wavelength range from $230-350 \mathrm{~nm}$, applying as reference the parameters proposed by Gallagher (2011). PCR reactions were performed in volumes of $12.5 \mu \mathrm{l}$ and $0.5 \mu \mathrm{l}$ of sample. Negative and positive control (Cedrela spp) reactions were also performed.

The ITS1 region of samples was amplified in two short and overlapping fragments, applying the combination of primers ITS1.1 (5' GAA CCT GCG GAA GGA TCA T 3') and ITS2.1 (5' GAC TCG ATG RTT CAC GGG 3') developed by Hansen et al. (2011).

The PCR reactions were performed in a thermocycler using $94^{\circ} \mathrm{C}$ for denaturation temperature, $55^{\circ} \mathrm{C}$ and $30 \mathrm{~s}$ for annealing and $72{ }^{\circ} \mathrm{C}$ and $30 \mathrm{~s}$ for extension, in a total of 40 cycles. The effectiveness of the reaction was verified by $1.5 \%$ 
agarose gel electrophoresis at $70 \mathrm{~V}$ for $70 \mathrm{~min}$ with a $100 \mathrm{bp}$ ladder for comparison. The gel was stained with $0.000002 \%$ ethidium bromide for $10 \mathrm{~min}$ and photographed in a UV transilluminator. The successful PCR reactions were purified using the EXO-SAP-IT enzyme following the manufacturer's recommendations.

Sequencing reactions were done with Big Dye ${ }^{\odot}$ Terminator enzyme kit, v.3.1 using cycle sequencing. For each sample, three reactions in directions from $3^{\prime}$ to $5^{\prime}$ and from 5' to 3' were evaluated. The reactions were incubated in a thermocycler, with initial denaturation at $96{ }^{\circ} \mathrm{C}$ for 1 minute, followed by 40 cycles of $15 \mathrm{~s}$ at $96^{\circ} \mathrm{C}, 30 \mathrm{~s}$ at $55^{\circ} \mathrm{C}, 4$ min at $60^{\circ} \mathrm{C}$, and cooling at $4{ }^{\circ} \mathrm{C}$. Consensus PCR sequences were obtained and aligned using the MEGA (Molecular Evolutionary Genetics Analysis) program, version 5.1 (TAMURA et al., 2011), with interface of Clustal X 2.0 (LARKIN et al., 2007).

With the resulting sequences, the NCBI-BLAST (Basic Local Alignment Search) (ALTSCHUL et al., 1990) was applied to find similar sequences available in the GenBank database (BENSON et al., 2005). The 11 sequences with highest scores were aligned to the unknown sequence and a neighbor-joining test tree was designed based on the Kimura 2 method, which uses 1000 bootstrap repetitions.

\section{Results and Discussion}

\section{Anatomic identification}

The samples presented distinct growth rings; semi-ring porous, vessels solitary predominant, in radial multiples of 23, occasionally clustered, without deposits in vessels (Figure 1A-B). Simple perforate plate (Figure 1D); intervessel pits alternate (Figure 1F), small; vessel ray pits with distinct borders, similar to intervessel pits in size and shape throughout the ray cell. Axial parenchyma paratracheal unilateral and vasicentric, tending to lozenge-aliform, confluent and scanty also present. Heterogeneous ray (Figure 1C), body ray cells procumbent with 1-4 rows of upright and/or square marginal cells, uniseriate and multiseriate, larger rays with 4-5 cell width and approximately 20 cell height, not storied (Figure 1E). Isolated crystals occasionally present in ray margin. Fibers thin to thick-walled, nonseptate.

The anatomical characteristics observed were compared with the descriptions of the identification keys of InsideWood (2004) and Record; Hess (1949). The results showed similarity with two genera: Citharexyllum, from the Verbenaceae family, and Hovenia, from the Rhamnaceae family. In the literature, descriptions of species from the genus Citharexyllum detail the presence of multiple perforation plates in addition to single perforation plates, and also the confluence of axial parenchyma forming irregular or marginal bands and the presence of septate fibers (SIEGLOCH et al., 2013; MARCATI et al., 2014), characteristics not observed in the samples of this study.

In the case of the Hovenia genus, the literature reports variation in distribution and percentage of axial parenchyma in function of origin and tree adaptation (INSIDEWOOD, 2004; GUPTA; SAXENA, 2011), but always a single perforation plate. Based on data described, a comparison between the unknown sample with images from histological sections from Citharexylum myrianthum and Hovenia dulcis (Figure 2) were done.

Based on the information's and comparative images, we concluded that the samples are from the genus Hovenia, an exotic tree introduced in the region and cultivated for fruit and ornamentation (RIGATO et al., 2001), considered an invasive species because of easy dispersion of seeds (LIMA et al., 2015). 


\section{Biomolecular identification - DNA}

The sequencing of ITS1 region was possible and two overlapping sequences were obtained, resulting in a sequence with $330 \mathrm{pb}$. This sequence was deposited in the GenBank related to code KT159700. When the resulting sequence was compared to data already available in the GenBank, all first
100 sequences with more similarity corresponded to a sample from the Rhamnaceae family. After pairing the 11 sequences with highest scores and constructing the nearest neighbor cluster tree (Figure 3), it was possible to observe that the three nearest sequences corresponded to ITS1 region of the genus Hovenia.
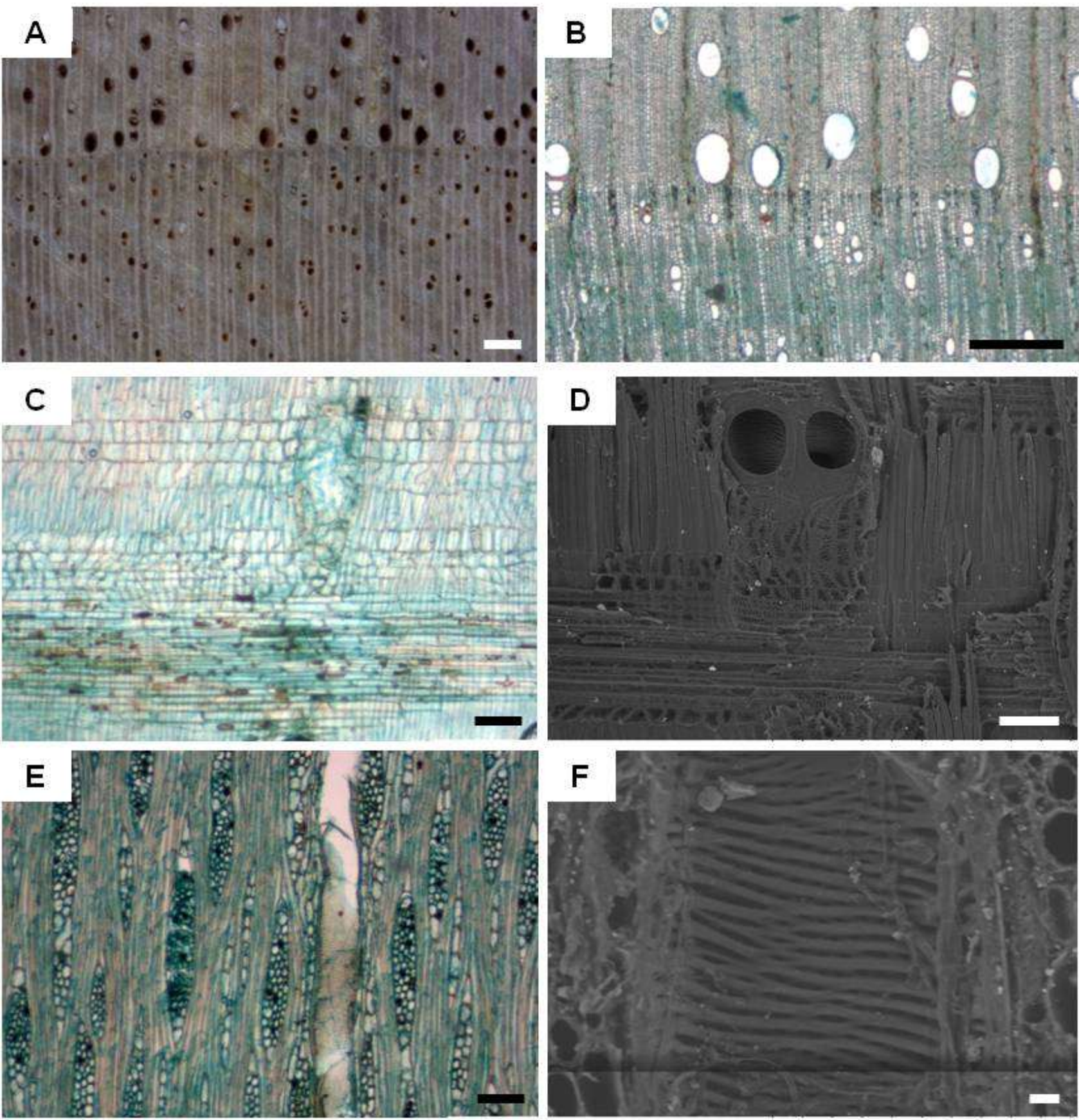

Figure 1. Unknown sample: macroscopic image (A), microscopic image (B, C, E) and SEM images (D, F). Transversal (A, B), radial (C, D) and tangential (E, F) sections of wood. Scale bar $=500 \mu \mathrm{m}(\mathrm{A}, \mathrm{B})$ and $=100 \mu \mathrm{m}(\mathrm{C}-\mathrm{F})$.

Figura 1. Amostra desconhecida: imagem macroscópica (A), imagem microscópica (B, C, E) e imagens em microscopia de varredura (D, F). Seção transversal (A, B), radial (C, D) e tangencial (E, F). Barra de escala $=500 \mu \mathrm{m}(\mathrm{A}, \mathrm{B}) \mathrm{e}=100 \mu \mathrm{m}(\mathrm{C}-\mathrm{F})$. 

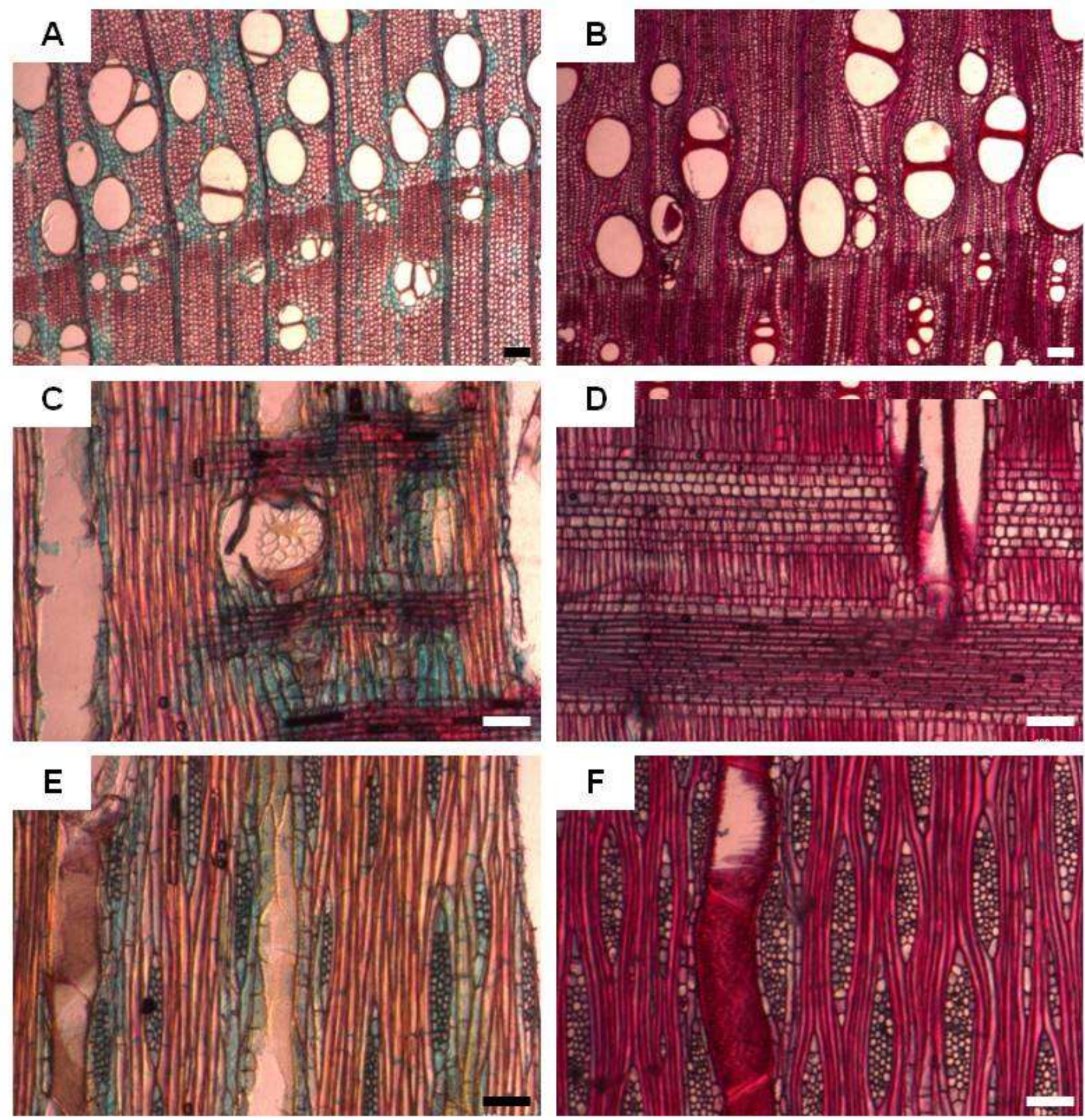

Figure 2. Microscopic image from Citharexylum myrianthum (A, C, E) and Hovenia dulcis (B, D, F). Transversal (A, B), radial $(C, D)$ and tangential (E, F) sections of wood. Scale bar $=100 \mu \mathrm{m}$

Figura 2. Imagens microscópicas de Citharexylum myrianthum (A, C, E) e Hovenia dulcis (B, D, F). Seções transversal (A, B), radial (C, D) e tangential (E, F) da madeira. Barra de escala $=100 \mu \mathrm{m}$

When observing the alignment of the ITS1 sequence of the studied sample and the sequences for the specimens of Hovenia dulcis and Hovenia acerba (Figure 4), the ITS1 region from the unknown wood is more similar to sequences identified as H. acerba.
The sequence from the unknown sample is more similar to the sequence KP093127, with the difference between them being the substitution of three nitrogenous bases (at 16, 133 and $222 \mathrm{pb})$. The sequence DQ146607 presented 18 substitutions of nitrogenous bases (at 39, 66, 77, 81, 82, 85, 89, 


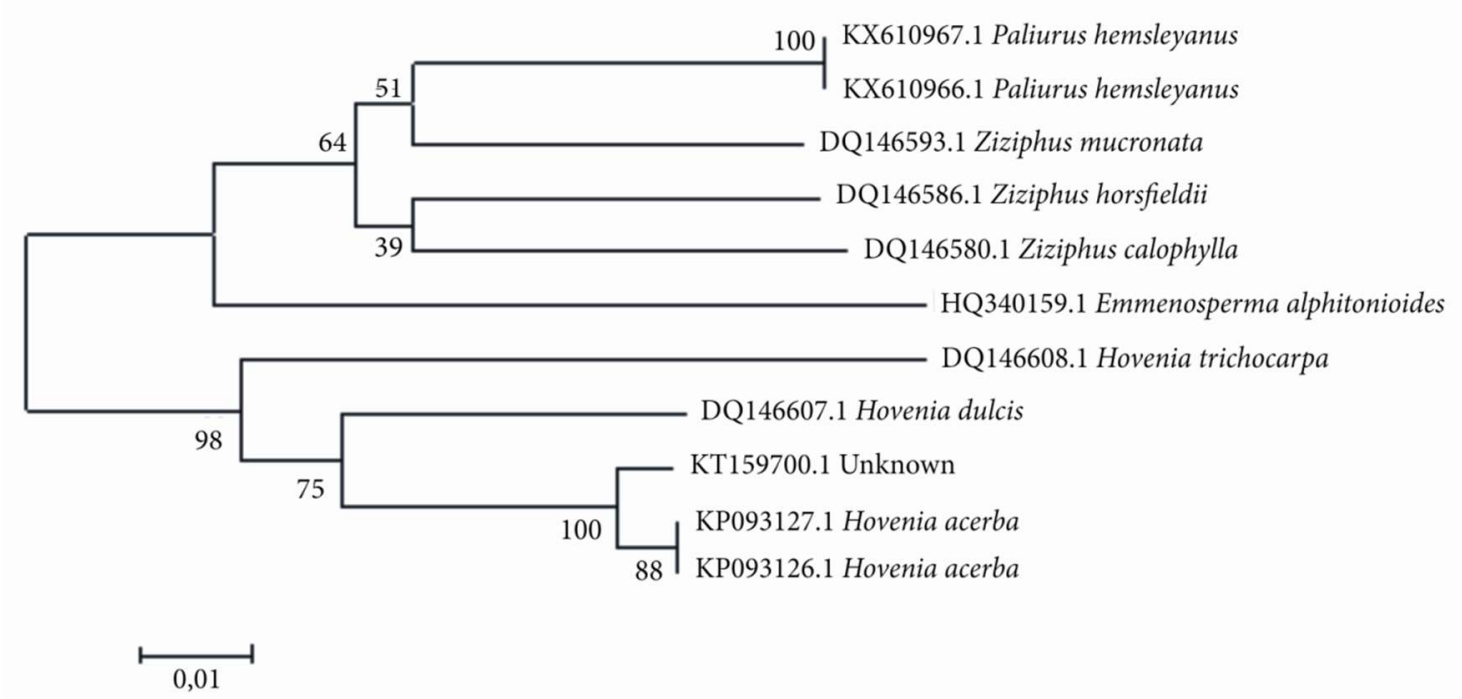

Figure 3. Nearest neighbor cluster tree for 11 sequences from GenBank and ITS1 region.

Figura 3. Árvore de agrupamento do vizinho mais próximo para 11 sequências do GenBank e região ITS1.

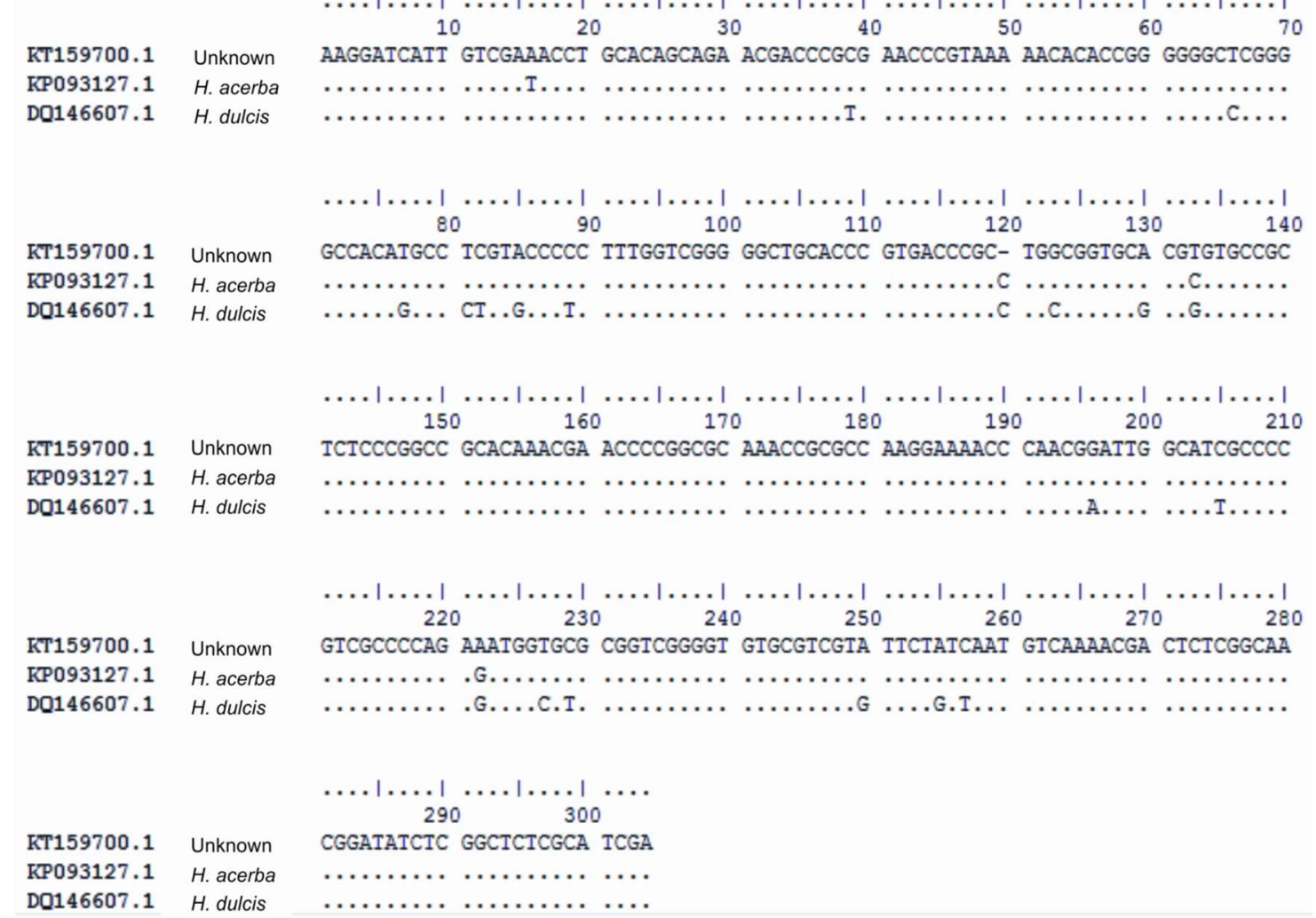

Figure 4. Alignment of ITS1 regions from unknown sample with Hovenia dulcis and Hovenia acerba.

Figura 4. Alinhamento da região ITS1 da amostra desconhecida com Hovenia dulcis e Hovenia acerba.

$122,130,133,196,205,222,227,229,250,255$ and 257pb.) when compared to the unknown sample. From the nitrogenous base number $120 \mathrm{pb}$, it is possible to infer the ITS1 region of the sample presents a cytosine base deletion.
This analysis indicated that the identification based on the ITS1 region converged with the wood anatomy results. But this conclusion could only be reached as a function of the previous studies of Islam; Simmons (2006) and Liu et al. (2015), which resulted in the sequences available today in the 
GenBank. For higher resolution identification based on the ITS1 region, we suggest that a larger number of specimens from this genus be sampled, and the variations in this region conserved in DNA be mapped.

Another suggestion is the application of the complete ITS region and more cpDNA and mDNA markers, like in the study from the China Plant Bol Group (2011), which sampled 6,286 specimens from 1,575 species, 145 genera and 75 families. DNA of these specimens was amplified from the traditional regions $r b c L$, matK, $t r n H-p s b A$ from plastidial DNA and ITS region from nuclear DNA. The efficiency of these markers for species discrimination and its universality were evaluated, presenting effectiveness of $88 \%$ for angiosperm samples and $56 \%$ for gymnosperms. The success rate of the sequencing was of $89.8 \%$ for angiosperms and $67 \%$ for gymnosperms. They also related that when just ITS5 and ITS4 primers were applied with unidirectional sequencing, the ITS1 region was successful for $71.7 \%$ of the specimens, $75.5 \%$ of species, and problems were only observed with parallel copies in $7.4 \%$ of the specimens, while $2.5 \%$ of the sequences were contaminated by fungi. The ITS region returned high quality sequences for $58.6 \%$ of the data. In analysis with bidirectional sequencing, the ITS region presents a convergent rate between sequences of $93.6 \%$, the highest of all. The ITS region presents higher discriminating power (67.2\% of all species) and increased that power, in addition to other markers, by $20 \%$.

Literature reports the difficulties in analysis of extracts from heartwood but indicate there is possible and with the obtainment of adequate results. For example, DNA extracts from heartwood of Dalbergia odorifera and Dalbergia tonkinensis was invisible in $1 \%$ algarose gel after electrophoresis due to low yield, and success rates for polymerase chain reaction (PCR) amplification in ITS was 62.5\% (YU et al., 2016) and in DNA extracts from heartwood of Aquilaria sinensis funghi contamination was found in material from 39 years old xylarium sample (JIAO et al., 2014).

Also, the use of ITS region and other markers are present in wood discrimination with different classifications. Evaluating Dalbergia species, with different markers and systems, Hartvig et al. (2015) concluded that in average over all discrimination methods, the ITS barcode had the highest correct identification rates (78\%), and $\mathrm{rbcL}$ had the lowest (53\%). The single highest correct identification rate was obtained for the matK+ITS and rbcL+matK+ITS barcode using TaxonDNA, reaching 100\% identification success and commented that ITS had the highest efficiency in identification of specimens in Dalbergia, alone or in combination with matK. In the same genus, Yu et al. (2017) concluded that ITS2 combined with $t r n H-p s b A$ was the best combination of DNA barcode for the Dalbergia wood species studied and demonstrated the feasibility of building a DNA barcode reference database using xylarium wood specimens.

The China Plant BOL Group (2011) recommends that ITS region should be added to the core plant barcode for seed plants because, in comparison to $r b c \mathrm{~L}, \operatorname{mat} \mathrm{K}, p s b \mathrm{~A}-t r n \mathrm{H}$ shows the highest discrimination power. Evaluating Pterocarpus species, Jiao et al. (2018) verified that among the four DNA barcodes, ITS2 had the highest proportion of variable (32.05\%) and informative (29.49\%) sites and among the single barcodes, ITS2 had the highest variation in interspecific divergence compared to the range of intraspecific distances. They also concluded that ITS2 showed the highest success rate $(85.1 \%)$, in species identification.

\section{Conclusions}

The wood sample from illegal logging was identified by wood anatomy and ITS1 region as from the genus Hovenia, which is an exotic and invader species that can be explored. 
We recommend mapping the ITS region for a higher number of specimens from the Rhamnaceae family and Hovenia species, and the test of other markers sequences, from cpDNA and mDNA, in identification analysis.

\section{Acknowledges}

This study was financed in part by the Coordenação de Aperfeicoamento de pessoal de Nivel Superior - Brasil (CAPES) - Finance Code 001 and Conselho Nacional de Desenvolvimento Científico e Tecnológico (CNPq).

\section{References}

ALTSCHUL, S.F.; GISH, W.; MILLER, W.; MYERS, E.W.; LIPMAN, D.J. Basic local alignment search tool. Journal of Molecular Biology, v.215, n.3, p.403-410, 1990.

ASIF, M.J. ; CANNON, C.H. DNA extraction from processed wood: a case study for the identification of an endangered timber species (Gonystylus bancanus). Plant Molecular Biology Report, v.23, n.2, p180-187, 2005.

BENSON, D.A.; KARSCH-MIZRACHI, I.; LIPMAN, D.J.; OSTELL, J.; WHEELER, D.L. GenBank. Nucleic Acids Researh, v.33, p.33-38, 2005.

BHARGAVA, M.; SHARMA, A. DNA barcoding in plants: evolution and applications of in silico approaches and resources. Molecular Phylogenetic Evolution, v.67, n.3, p.631-641, 2013.

BOLSON, M.; SMIDT, E.C.; BROTTO, M.L.; SILVA-PEREIRA, V. ITS and trnH-psbA as efficient DNA barcodes to identify threatened commercial woody angiosperms from Southern
Brazilian Atlantic Rainforests. Plos One, 10:e0143049, 2015.

BORGES, K.C.A.S.; DIAS, S.M.; MENDONÇA, E.G.; LELIS, R.C.C.; SANTOS, L.A.; SOUZA, S.R. DNA extraction and anatomic characterization in dried heartwood from Fabaceae species. Wood Research, v.2, n.1, p.13-26, 2017.

CHINA PLANT BOL GROUP. Coparative analysis of large dataset indicates that internal transcribed spacer (ITS) should be incorporated into the core barcode for seed plants. Proceedings of the National Academy of Sciences of USA, v.108, p.19641-19646, 2011.

DEGEN, B.; WARD, S.E.; LEMES, M.R.; NAVARRO, C.; CAVERS, S.; SEBBENN, A.M. Verifying the geographic origin of mahogany (Swietenia macrophylla King) with DNAfingerprints. Forensic Science International: Genetics, v.7, n.1, p.55-62, 2013.

DUJARDIN, E.P. Eine neue HolzZellulosenfaerbung. [A new wood-cellulosic coloring] Mikrokosmos, n.53, p.94, 1964.

FINKELDEY, R.; LEINEMANN, L.; GAILING, O. Molecular genetic tools to infer the origin of forest plants and wood. Applied Microbiology and Biotechnology, v.85, n.5, p.1251-1258, 2010.

FORD, S.C.; AYRES, K.L.; TOOMEY, N.; HAIDER, N.; STAHL, J.A.; KELLY, L.J. et al. Selection of candidate coding DNA barcoding regions for use on land plants. Botanical Journal of Linneum Society, v.159, n.1, p.1-11, 2009.

GALLAGHER, S.R. Quantitation of DNA and RNA with absorption and fluorescence spectroscopy. Current Protocols in Neuroscience, A.1.K1-A.1K, 2011. 
GAO, T.; YAO, H.; SONG, J.; LIU, C.; ZHU, Y.; $\mathrm{MA}, \mathrm{X}$. et al. Identification of medicinal plants in the family Fabaceae using a potencial DNA barcode ITS2. Journal of Ethnopharmacology, v.130, n.1, p.116-121, 2010.

GASSON, P. How precise can wood identification be? Wood Anatomy's Role in Support of the Legal Timber Trade, Especially CITES. IAWA Journal, v.32, n.2, p.137-154, 2011.

GUPTA, S.; SAXENA, V. Wood microstructure of ligneous species of Rhamnaceae from India. Journal of Tropical Forest Science, v.23, n.3, p.239-251, 2011.

HANSEN F, WISCHNEWSKI N, MORETH U, MAGEL AE. Molecular Identification of Fitzroya cupressoides, Sequoia sempervirens, and Thuja plicata wood using Taxon-Specificic rDNA-ITS primers. IAWA Journal, v.32, n.2, p.273-284, 2011.

HARTVIG, I.; CZAKO, M.; KJAER, E.D.; NIELSEN, L.R.; THEILADE, I. The use of DNA barcoding in identification and conservation of rosewood (Dalbergia spp.). PLoS ONE, v.10, n.9, e0138231, 2015.

HILLIS, D.M.; DAVIS, S.K. Evolution of ribossomal DNA: Fifty Million Years of Recorded History in the frog genus Rana. Evolution, v.40, n.6, p. 1275-1288, 1986.

IAWA. International Association of Wood Anatomists. List of microscopic features for hardwood identification. IAWA Bulletin, v.10, n.3, p.219-332, 1989.

INSIDEWOOD. 2004-onwards. Disponível em: http://insidewood.lib.ncsu.edu/search. Acesso em : 03 de set. de 2014.
ISLAM, M.B.; SIMMONS, M.P. A thorny dilemma: testing alternative intrageneric classifications within Ziziphus (Rhamnaceae). Systematic Botanic, v.31, n.4, p.826-842, 2006.

JIAO, L.; YIN, Y.; CHENG, Y.; JIANG, X. DNA barcoding for identification of the endangered species Aquilaria sinensis: comparasion of data from heated or aged wood samples. Holzforschung, v.68, n.4, p.487-494, 2014.

JIAO, L.; YU, M.; WIEDENHOEFT, A.C.; HE, T.; LI, J.; LIU, B.O.; JIANG, X.; YIN, Y. DNA barcode authentication and library development for the wood of six commercial Pterocarpus species: the critical role of xylarium specimens. Scientific Reports, n.8, p.1945, 2018.

KOCH, G.; RICHTER, H.J.; SCHMITT, U. Design and application of CITES wood ID-Computeraided identification and description of CITESprotected timbers. IAWA Journal, v.32, n.2, p. 213-220, 2011.

LARKIN, M.A.; BLACKSHIELDS, G.; BROWN, N.P.; CHENNA, R.; MCGETTIGAN, P.A.; MCWILLIAN, $\mathrm{H}$. et al. Clustal W and Clustal X version 2.0. Bioinformatics, v.23, n.1, p.2947-2948, 2007.

LI, X.; YANG, Y.; HENRY, R.J.; ROSSETTO, M.; WANG, Y.; CHEN, S. Plant DNA barcoding: from gene to genome. Biological Review, v.90, n.1, p.157-166, 2015.

LIEPELT, S.; SPERISEN, C.; DEGUILLOUX, M.F.; PETIT, R.J.; KISSLING, R.; SPENCER, M. et al. Authenticated DNA from ancient wood remains. Annals of Botany, v.98, n.5, p.1107-1111, 2006.

LIMA, R.E.M.; DECHOUM, M.S.; CASTELLANI, T.T. Native seed dispersers may promote the spread of the invasive Japanede raisin tree (Hovenia 
dulcis Thunb.) in seasonal deciduous forest in southern Brazil. Tropical Conservation Science, v.8, n.3, p.846-862, 2015.

LIU, J.; YAN, H.; NEWMASTER, S.G.; PEI, N.; RAGUPATHY, S.; GE, X. The use of DNA barcoding as a tool for the conservation biogeography of subtropical forests in China. Diversity and Distribution, v.21, n.2, p.188-199, 2015.

LOWE, A.J.; CROSS, H.B. The application of DNA methods to timber tracking and origin verification. IAWA Journal, v.32, n.2, p.251-262, 2011.

MAGEL, E. Physiology of cambial growth, storage of reserves and heartwood formation. In. Huttunen S, Bucher J, Sundberg B, Jarvis P, Matyssek R, editors. Tree Physiology, Trends in European Forest Tree Physiology Research. Cost Action E6: EUROSILVA, 2001, p.19-32.

MARCATI, C.R.; LONGO, L.R.; WIEDENHOEF, A.; BARROS, C.F. Comparative wood anatomy of root and stem of Citharexylum myrianthum (Verbenaceae). Rodriguésia, v.65, n.3, p.567-576, 2014.

RACHMAYANTI, Y.; LEINEMANN, L.; GAILING, O.; FINKELDEY, R. DNA from processed and unprocessed wood: factors influencing the isolation success. Forensic Science International: Genetics, v.3, n.3, p.185-192, 2009.

RECORD, S.J.; HESS, R.W. Timbers of the New World. New Haven: Yale University Press, 1949. 640p.

RIGATTO, P.A.; PEREIRA, J.C.D.; MATTOS, P.P.; SCHAITZA, E.G. Características físicas, químicas e anatômicas da madeira de Hovenia dulcis. Colombo, Embrapa: Comunicado Técnico 66, 2001.
SARMIENTO, C.; DÉTTIENE, P.; HEINZ, C.; MOLINO, F.; GRARD, P.; BONNET, P. Pl@ntWood: a computer-assisted identification tool for 110 species of amazons trees based on wood anatomical features. IAWA Journal, v.32, n.2, p.221-232, 2011.

SIEGLOCH, A.M.; MARCHIORI, J.N.C.; SANTOS, S.R. Estudo anatômico da madeira de Citharexylum montevidense Moldenke (Verbenaceae). Balduinia, v.42, p.27-32, 2013.

TAMURA, K.; PETERSON, D.; PETERSON, N.; STECHER, G.; MASATOSHI, N.; KUMAR, S. MEGA 5: Molecular evolutionary genetics analysis using maximum likelihood, evolutionary distance, and maximum parsimony methods. Molecular Biology and Evolution, v.28, n.10, p.2731-2739, 2011.

TEREBA, A.; WOODWARD, S.; KONECKA, A.; BORYS, M.; NOWAKOWSKA, J.A. Analysis of DNA profiles of ash (Fraxinus excelsior L.) to provide evidence of illegal logging. Wood Science and Technology, v.51, n.6, p.1377-1387, 2017.

TNAH, L.H.; LEE, S.L.; NG, K.K.S.; BHASSU, S.; OTHMAN, R.Y. DNA extraction from dry wood of Neobalanocarpus heimii (Dipterocarpaceae) for forensic DNA profiling and timber tracking. Wood Science and Technology, v.46, n.5, p.813-825, 2012.

WHEELER, E.A.; BAAS, P. Wood Identification A Review. IAWA Journal, v.19, n.3, p.241-264, 1998.

WICKE, S.; COSTA, A.; MUÑOS, J.; QUANDT, D. Restless 5S: The re-arrangement(s) and evolution of the nuclear ribossomal DNA in land plants. Molecular Phylogenetics and Evolution, v.61, n.2, p.321-332, 2011. 
YU, M.; JIAO, L.; GUO, J.; WIEDENHOEFT, A.C.; HE, T.; JIANG, X.; YIN, Y. DNA barcoding of vouchered xylarium wood specimens of nine endangered Dalbergia species. Planta, v.246, p.1165-1176, 2017.

YU, M.; LIU, K.; ZHOU, L.; ZHAO, L.; LIU, S. Testing three proposed DNA barcodes for the wood identification of Dalbergia odorifera T. Chen and Dalbergia tonkinensis Prain. Holzforschung, v.70, n.2, p.127-136, 2016.

ZHANG, R.; XU, K.; YE, K. Concentration and distribuition of nuclei and plastids in xylem cells in Cunninghamia lanceolata and Aquilaria sinensis.

BioResources, v.10, n.1, p.1304-1317, 2015. 